\title{
Biogeography of Groundfish Assemblages on the Grand Bank
}

\author{
M. C. Gomes and R. L. Haedrich \\ Department of Biology and Ocean Sciences Centre, \\ Memorial University of Newfoundland, \\ St. John's, Newfoundland, Canada A1B 3X7. \\ and \\ J.C. Rice \\ Department of Fisheries and Oceans, \\ Pacific Biological Station, \\ Nanaimo, British Columbia, Canada V9R 5K6
}

\begin{abstract}
A 16-year time series (1971-82, 1984-87) of data from spring groundfish surveys was analyzed to identify, describe, and map six broad zoogeographic areas on the Grand Bank of Newfoundland, each characterized by a relatively homogeneous and persistent biological composition (a fish assemblage). The boundaries of these areas were strongly aligned with bottom depth and oceanographic features, confirming previous evidence from worldwide studies on the major determinants of the distribution of groundfish on continental shelves. Consideration of their overall biological coherence allowed a merging and reformulation of the original six assemblage areas into four coherent zoogeographic regions. Analysis of catch rates in the two major regions so defined suggested that species composition was relatively stable over time. Whether the Grand Bank assemblages correspond to groups of functionally-linked fishes remains an open question of considerable practical and theoretical interest. The definition of areas where species broadly recur and overlap provides a useful spatial scale for studies at the community level on the Grand Bank and has implications for multispecies management.
\end{abstract}

\section{Introduction}

A major goal in fisheries ecology studies is to understand changes in fish populations induced by natural phenomena and by man's exploitation. Fisheries biologists have developed a large body of literature on how to mathematically model these changes on a single-species basis (Megrey and Wespestad, 1988) but, because fisheries ecosystems are complex, growing international concern has called for alternative multispecies management (Mercer, 1982; May, 1984; Mahon, 1985) based on a better understanding of marine communities as a whole. The quest to understand a complex system is a search for pattern and for the reduction of complexity to a number of easily comprehensible rules. However, as aquatic ecologists have long recognized (Powell, 1989), pattern is largely dependent on scale and can be found at any level of investigation (O'Neill et al., 1986). More than just a conceptual framework, considerations of scale are increasingly important in ecology (O'Neill, 1989; Auster, 1988) and the questions that they raise should be dealt with at the outset of any community study (Underwood, 1986).
We propose that a reasonable initial approach to the definition of spatial scale appropriate for multispecies fisheries studies is to identify broad geographic areas that are characterized by a relatively homogeneous (constant in space) and persistent (constant in time) biological composition. Such areas are referred to as "fish assemblage areas" (Tyler et al., 1982; Overholtz, MS 1983; Mahon et al., 1984) and are defined "solely on the basis of [species'] geographic distribution" (Tyler et al., 1982). Fish assemblage areas are appropriate geographic compartments for modelling and/or management purposes. Attention can be directed to investigate biological variability and organizational structure within each area, as well as interactions between areas.

Our study was intended to identify, describe, and map broad groundfish assemblage areas on the Grand Bank of Newfoundland (NAFO Div. 3LNO). We have used a statistical analysis of co-occurrence of species in the catches of groundfish surveys and then assessed the biological validity of the areas so generated from considerations of stock discrimination. We suggest that the resulting zoo- 
geographic understanding of the Grand Bank defines a useful spatial scale for multispecies studies on the Bank, but still acknowledge that little is known about the extent to which populations interact within such areas.

\section{Materials and Methods}

Stratified-random groundfish spring surveys have been conducted in NAFO Div. 3LNO off Newfoundland since 1971. The research vessel A.T. Cameron conducted the surveys until 1984, at which time it was replaced by the Wilfred Templeman. Tows were for 30 min. at 2.5 knots. Stratification was by latitude, longitude and depth. Sets were allocated to strata according to area, with all strata containing at least two sets. Bottom temperatures were recorded on each set. Temperatures differed from year to year as well as from site to site, but generally were in the range of $-1.5^{\circ}$ to $+9^{\circ} \mathrm{C}$. Biological data from the annual surveys were analyzed for each of 16 spring seasons (1971-82, 1984-87) using standard classificatory techniques. For each spring a two-way data matrix (stations $x$ species) was built, whose entries ij were the catch in weight of species $j$ at fishing station $i$. Species were in- cluded in the analysis if their biomass comprised at least $0.1 \%$ of the total catch in a given spring. The number of species varied between 29 and 34; Table 1 shows the 30 species most commonly encountered. The data were log-transformed before conducting the analysis. The transformation was not aimed at achieving multivariate normalization, but rather to correct for the exponential nature of differences in species abundance (Gauch, 1982).

Cluster analysis was applied to identify groups of species that tended to occur together year after year. The Bray-Curtis index (Clifford and Stephenson, 1975) was used to measure dissimilarity between each pair of stations. This index ranges from zero (identical stations) to unity (dissimilar stations), and in addition to performing well in measuring overlap in simple simulated situations (Bloom, 1981), the coefficient has appealing properties in the fisheries context, especially regarding its sensitivity to abundant species (Gabriel, MS 1983; Sinclair, 1985; Gomes, MS 1987, MS 1991). Observations (fishing stations) were clustered by two agglomerative polythetic methods: Group Average (Clifford and Stephenson, 1975) and Ward's Minimizing Error Sum of Squares (Ward, 1963). Even

TABLE 1. List of common and scientific names of species used in the analysis and referred to in the text.

\begin{tabular}{lc}
\hline \hline Common name & \\
\hline Angler, Common & Scientific name \\
Argentine, Atlantic & Lophius americanus \\
Capelin & Mallotus villosus \\
Cod, Atlantic & Gadus morhua \\
Eelpouts & Lycodes spp. \\
Eelpout, Vahl's & Lycodes vahlii \\
Eelpout, Arctic & Lycodes reticulatus \\
Greenland halibut & Reinhardtius hippoglossoides \\
Haddock & Melanogrammus aeglefinus \\
Hake, Longfin & Urophycis chesteri \\
Hake, Silver & Merluccius bilinearis \\
Hake, White & Urophycis tenuis \\
Halibut & Hippoglossus hippoglossus \\
Longhorn sculpin & Myoxocephalus octodecemspinosus \\
Lumpfish, Common & Cyclopterus lumpus \\
Marlin-spike & Nezumia bairdii \\
Plaice, American & Hippoglossoides platessoides \\
Pollock & Pollachius virens \\
Redfish & Sebastes spp. \\
Roughhead grenadier & Macrourus berglax \\
Sea raven & Hemitripterus americanus \\
Shorthorn sculpin & Myoxocephalus scorpius \\
Smooth skate & Raja senta \\
Spiny dogfish & Squalus acanthias \\
Thorny skate & Raja radiata \\
Witch flounder & Glyptocephalus cynoglossus \\
Wolffish, Broadhead & Anarhichas denticulatus \\
Wolffish, Spotted & Anarhichas minor \\
Wolffish, Striped & Anarhichas lupus \\
Yellowtail flounder & Limanda ferruginea \\
\hline
\end{tabular}


though Ward's method was originally developed for use with euclidian distances, there is considerable empirical and formal evidence suggesting that it performs well even with non-metric distances (Batagelj, 1988) such as with the Bray-Curtis index. These two clustering techniques had previously been successfully applied to groundfish data by Gomes (MS 1987). All calculations were carried out using the CLUSTAN package (Wishart, 1982).

Results were assessed for validity by four different methods: (1) mapping the clusters and checking for geographical continuity of stations belonging to the same cluster, (2) visual confirmation of cluster coherence in the two-way table yielded by TWINSPAN (see below), (3) using Jardine and Sibson's (1971) deltas (procedure COMPARE of CLUSTAN), and (4) analysis of randomly chosen matrices using the relocation procedure (procedure RELOCATE of CLUSTAN) and comparing the results with those previously found by Group Average and Ward's method. Convergence of the results of RELOCATE with those of Group Average and Ward's method was taken as good evidence that a global optimum had been found (Wishart, 1982).

Two-way tables generated by TWINSPAN (Hill, 1979) allowed the recognition of biological features of each of the main station groupings identified by cluster analysis. This method, a refined and computerized version of a polythetic divisive method based on an ordination technique ("Indicator Species Analysis", Hill et al., 1975), gives results that fulfil requirements of non-exclusivity, i.e., an ubiquitous species can be associated with more than one cluster of stations unlike other interpretation techniques, for example nodal analysis (Lambert and Williams, 1962). The biological features included not only actual differential species (species having a clear preference for a given cluster) but also the presence or absence of a very widespread species in a cluster and anomalies in cluster richness (number of species present). These features were used on a regular basis to classify stations laid off the main clusters or to ratify the classification of those ambiguous stations usually located on geographical boundaries of the areas occupied by the main station groups.

\section{Zoogeographic Groups}

The geographical distribution of the most abundant groundfish species was consistently coincident within relatively well-defined areas year after year (1971-82, 1984-87). The contours of these biologically homogeneous areas were drawn for each year to produce a general zoogeographic picture of the Grand Bank in regard to the groundfish fauna. The main results are summarized below; for year-by-year results see Gomes (MS 1991).

Four major clusters of stations recurrently appeared in the dendrograms computed for each spring of the 16-year time-series. Each cluster was closely associated with bottom topography (Fig. 1). The zoogeographic areas comprising three of the clusters approximately followed isobaths near the edge of the Bank. There was a Shallow Group (stations shallower than $70 \mathrm{~m}$ ), an Intermediate Group (stations between $80 \mathrm{~m}$ and $200 \mathrm{~m}$ ) and a Deep Group (stations deeper than $200 \mathrm{~m}$ ). The fourth major cluster comprised stations just to the east of the Avalon Peninsula and was called the Avalon Group (stations between 70 and $180 \mathrm{~m}$ ). Both the Intermediate Group and the Deep Group were further subdivided into two subgroups of stations, each on the basis of apparent faunal differences: the Intermediate Group was subdivided into the NE Intermediate Sub-Group to the northeast and the SW Intermediate Sub-Group to the southwest. The Deep Group was subdivided into the NES Deep Sub-Group around the north, east and south of the Bank slope and the W Deep Sub-Group to the west (Fig. 2).

Each zoogeographic area had a characteristic composition of groundfish species, i.e. a fish assemblage, that recurrently co-occurred therein (Table 2). Although each assemblage underwent quantitative changes in species abundances, their taxonomic composition was remarkably constant over the 17-year period covered by the study. A more detailed description of each group follows:

\section{Shallow Group}

The Shallow Group occupied a major shallow area on the southeast Grand Bank. The eastern, southern and western borders of the Shallow Group lay near the $90 \mathrm{~m}$ isobath, and extended to the Whale Bank in the west and met the Avalon Group to the north. Stations had depths ranging from 40 to $100 \mathrm{~m}$, with average values around $70 \mathrm{~m}$ and standard deviations $12 \mathrm{~m}$ or less. Bottom temperatures were usually between $-1^{\circ}$ and $+2^{\circ} \mathrm{C}$. Four species dominated this group (Table 2): yellowtail flounder, American plaice, cod and thorny skate. Three other species also recurred, but in much lower abundance: striped wolffish, sea raven and longhorn sculpin. Striped wolffish was usually restricted to samples taken south of $45^{\circ} \mathrm{N}$ latitude.

\section{Avalon Group}

The Avalon Group occupied the zone around the Virgin Rocks, most of the Avalon Channel, and the southern Downing Basin (Fig. 2). Boundaries 


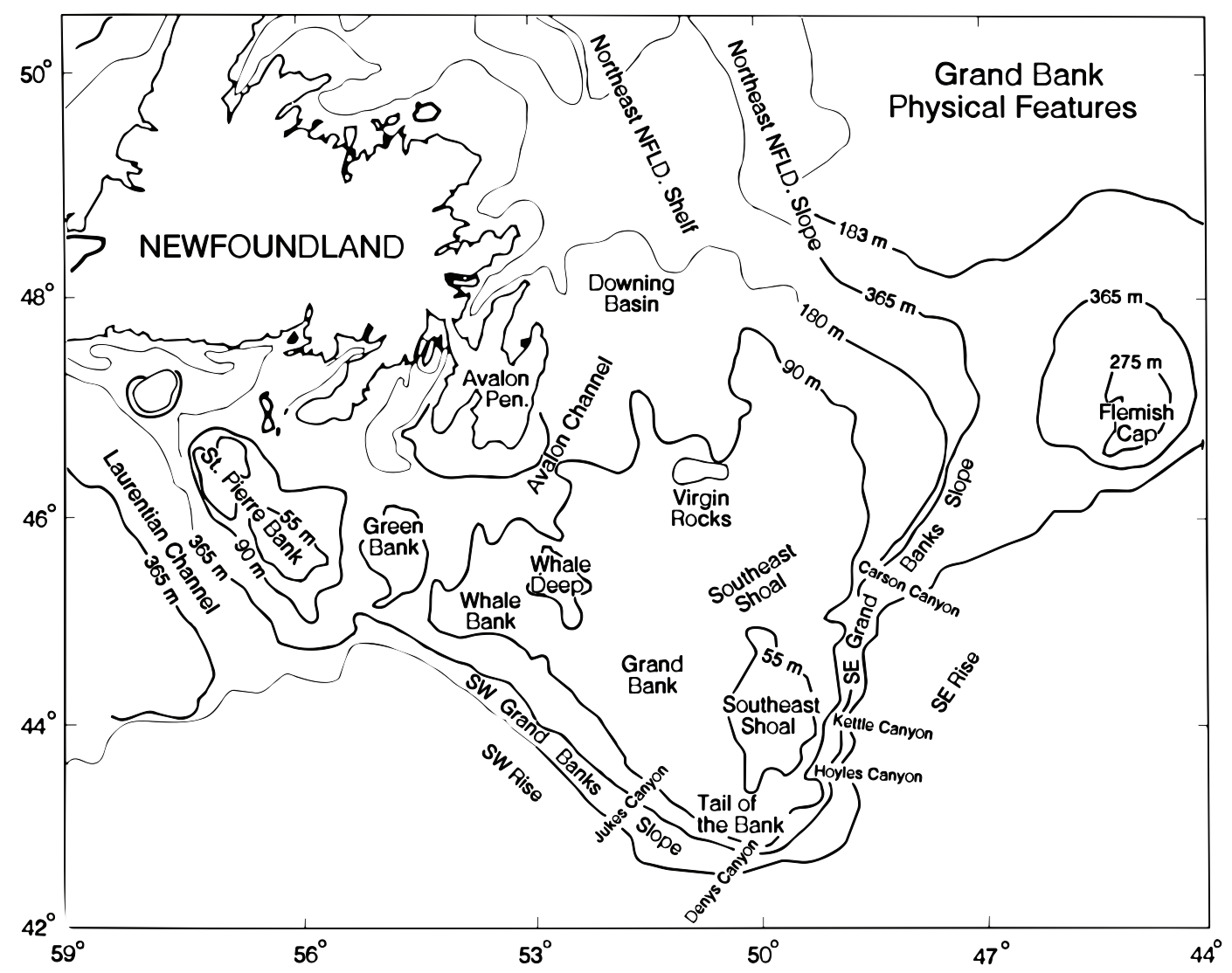

Fig. 1. Bathymetry and other physical features of the Grand Bank region.

changed position considerably from year to year (they can be expected to lie between lines $a$ and $a$ ' of Fig. 2 to the east, and lines $b$ and $b$ ' to the west). Station depths varied between 70 and $180 \mathrm{~m}$ with average values around $120 \mathrm{~m}$ and standard deviations between 25 and $40 \mathrm{~m}$. Bottom temperatures were between $-1.5^{\circ}$ and $0^{\circ} \mathrm{C}$. The Avalon Group contained two strong dominant species: American plaice and cod (Table 2). The third characteristic species was the Arctic eelpout, commonly present although in very low amounts. The group was remarkably poor in number of species relative to other areas of the Bank. Stations of this group were distinguished from the Shallow Group to the south by the disappearance of two important species: thorny skate and yellowtail flounder. These two species were not usually found north of a line between Whale Bank and Virgin Rocks. Yellowtail flounder was often caught further north than was thorny skate, mainly in the Virgin Rocks area. The differential distribution of these two species suggested the existence of an intermittent narrow transition zone between the Avalon Group and the Shallow Group (indicated in Fig. 2 with a different hatching pattern) where typical dominant species were cod, American plaice and yellowtail flounder with eelpout in very low abundance. The Avalon Group was distinguished from the Intermediate Group by the absence of thorny skate and a lower species richness (Table 2).

\section{Intermediate Group}

The Intermediate Group occupied a transition zone between the two shallow water groups (Shallow and Avalon) and the Deep Group (Fig. 2). Three species dominated: American plaice, cod and thorny skate (Table 2). Other species, much lower in abundance though constant in their presence, provided a basis upon which to subdivide the Intermediate Group into a NE Intermediate Sub-Group and a SW Intermediate Sub-Group.

NE Intermediate Sub-Group. The NE Intermediate Sub-Group occupied a vast area comprising the Downing Basin and much of the northeast Grand Bank (Fig. 2). Its southwest limit extended to near Carson Canyon (Fig. 1). Outer boundaries lay between the $200 \mathrm{~m}$ and $280 \mathrm{~m}$ isobaths on the slope. These boundaries were relatively variable in depth from one year to another, the exact placement dependent on the upper distribution limit of redfish, the dominant species in the NES Deep Sub-Group 


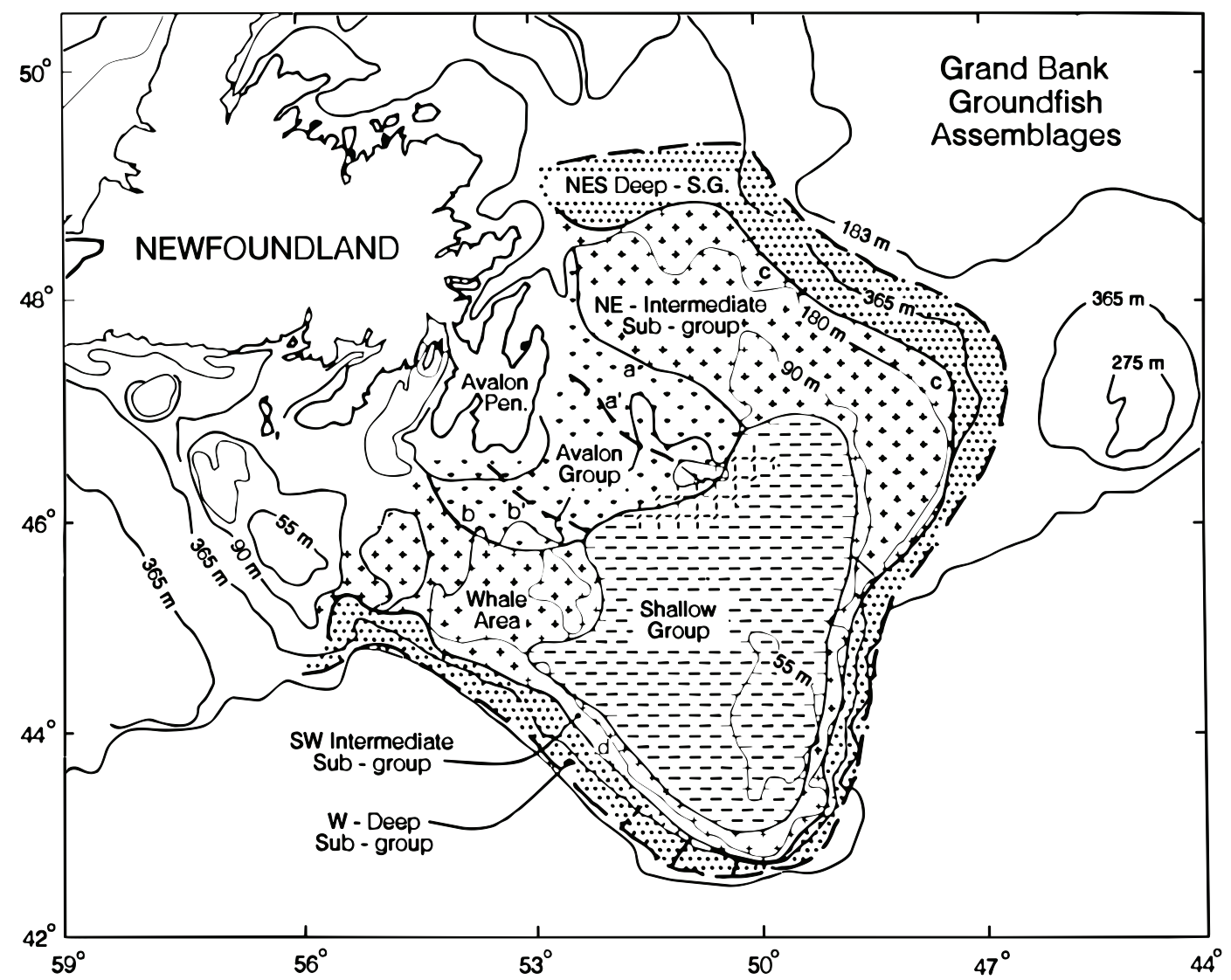

Fig. 2. Geographic distribution of the main clusters of stations on the Grand Bank. The contours presented were pooled out of 16 Spring seasons analyzed. They represent the most typical situation found, rather than any particular year. Different patterns cover areas with different fish assemblages. The Deep and Intermediate areas are subdivided into two sub-groups (see text).

(see below). The shallower limits were near the 90 $\mathrm{m}$ isobath with average depths around $150 \mathrm{~m}$ and standard deviations close to $50 \mathrm{~m}$. Bottom temperatures were between $-1.2^{\circ}$ and $+2.3^{\circ} \mathrm{C}$. This SubGroup included American plaice, cod and thorny skate (Table 2). Other species usually present in relatively low abundance were Arctic eelpout, Greenland halibut and wolffishes (especially spotted wolffish). Arctic eelpout was usually the more abundant of these lesser species, with a distribution mainly to the north and northeast of Carson Canyon but also often found in the Hoyles and Kettle Canyon region.

SW Intermediate Sub-Group. The SW Intermediate Sub-Group occurred along a narrow strip on the continental slope to the south and west (Fig. 2). Typical depths of stations were between 90 and 200 $\mathrm{m}$, with the average around $110 \mathrm{~m}$. In the Whale Bank area (Fig. 1), some stations were shallower than $90 \mathrm{~m}$. Difficulties arose for most years in determining the deeper boundary of this Sub-Group, not only due to yearly changes in the actual depth of the boundary but also because of imprecisions arising from the steep topography in the area. As with the previous Sub-Group, the position of the deeper boundary was set dependent on the upper limits of typical species in the Deep Group (see below). Throughout the year-by-year analysis, hakes and redfish from the W Deep Sub-Group appeared more prone to move above the 150-200 m depth zone in the southwest than in the north and east. The SW Intermediate Sub-Group was dominated by American plaice, thorny skate and cod (Table 2). Species recurring in much smaller amounts were witch flounder and striped wolffish. Localized incursion by species from deeper waters, especially redfish and hakes, was a frequent phenomenon. The SW Intermediate Sub-Group included the Whale Bank and the Whale Deep to the west of the Grand Bank (Fig. 1). The core of the Whale region seemed to be fairly constant in regard to the dominating presence of cod, thorny skate and American plaice. Most of the area, however, was prone to incursions by species typical of other assemblages. Stations to the north often resembled typical stations from 
the Avalon Group in that they lacked thorny skate and/or included Arctic eelpout which had extended its

TABLE 2. Species composition of the groundfish assemblages on the Grand Bank. Horizontal lines separate sets of species with decreasing orders of magnitude as expressed by $\mathrm{kg} / \mathrm{tow}$ in hauls. Within each order of magnitude, species are ranked by approximate decreasing order of abundance. Species without asterisks were present throughout the area of the assemblage in at least 13 of the 16 years. Species with $\left({ }^{*}\right)$ were also recorded in at least 13 , although in more restricted regions within the assemblage area. Species with (**) were recorded in 7 to 12 years out of 16 .

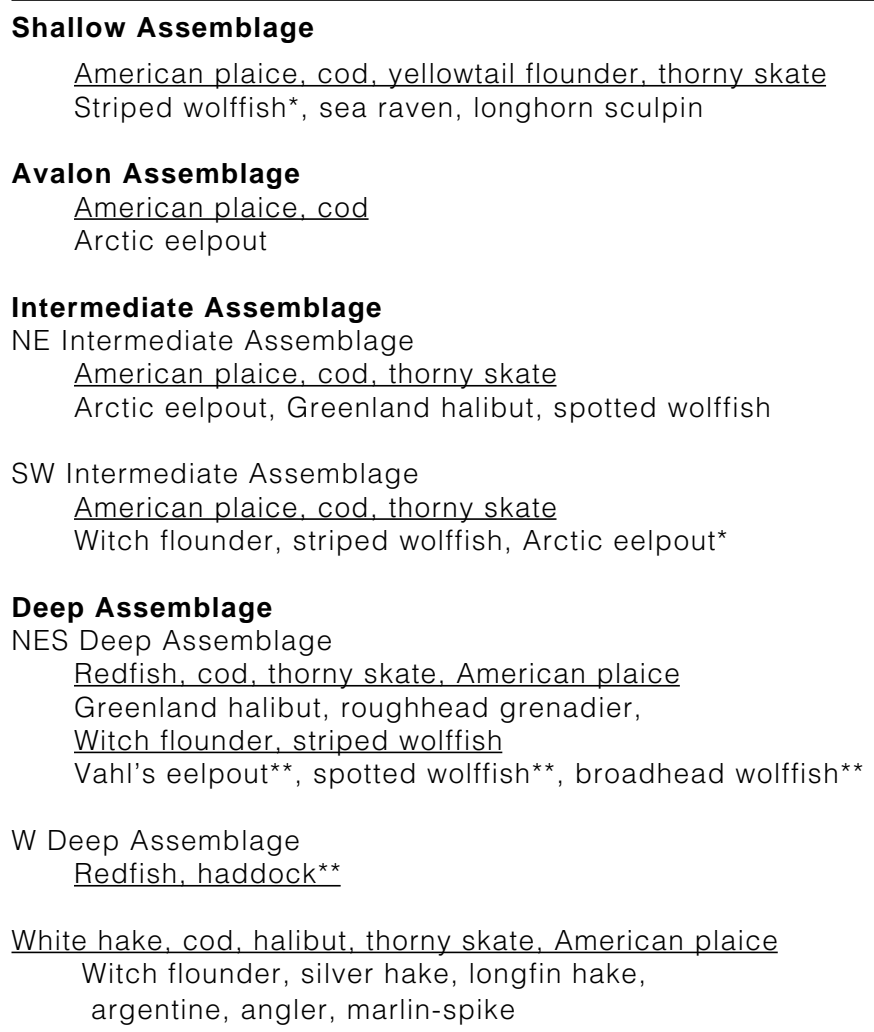

distribution all along the Avalon Channel. Yellowtail flounder, a typical representative of the Shallow Group, was often found to the south in the Whale region but shallower than $90 \mathrm{~m}$. Lumpfish, the main distribution of which is further to the north on the St. Pierre and Green Banks, was also sometimes found in significant amounts on Whale Bank. One other species occasionally found in the Whale region, as well as the rest of the SW Intermediate Sub-Group, was witch flounder.

\section{Deep Group}

The Deep Group encircled the Grand Bank below $200 \mathrm{~m}$ (Fig. 2). The upper depth limit was rather variable. Boundaries between the Deep and the Intermediate Group tended to become shallower to the south and west along the upper continental slope. To the west of the Grand Bank the boundary frequently lay shallower than $150 \mathrm{~m}$. The absence of samples deeper than $500 \mathrm{~m}$ precluded a full assessment of the outer limits of the Deep Group (expressed by a dashed line in Fig. 2). The Deep Group was dominated by redfish, but was also distinguished in being rich in species (Table 2). Differences in the relative importance of species other than redfish led to a subdivision of the group into a NES Deep Sub-Group and a W Deep SubGroup.

NES Deep Sub-Group. This Sub-Group occurred along the northern, eastern and southern borders of the Grand Bank. Its boundary with the W Deep Sub-Group was in the Tail of the Bank region, lying in a relatively unstable position between Denys and Jukes Canyons (Fig. 1 and 2). The shallow limit of the NES Deep Sub-Group to the north and east of the Grand Bank ranged between 180 and $280 \mathrm{~m}$ from year to year. These variations were mostly caused by irregular incursions of redfish to shal- 
lower waters. In some years a transition strip between the NES Deep Sub-Group and the NE Intermediate Sub-Group was identified, with redfish, Arctic eelpout, cod, thorny skate and American plaice being important species. To the southwest, the upper limit of the NES Deep Sub-Group became progressively more indeterminate, but it seemed to become somewhat shallower. Stations in the NES Sub-Group had average depths around $280 \mathrm{~m}$ and standard deviations around $50 \mathrm{~m}$. Bottom temperatures were warmer than in most other groups, ranging from $0^{\circ}$ to $4^{\circ} \mathrm{C}$. Three species dominated the NES Deep Sub-Group by abundance and constant presence: redfish, cod and thorny skate (Table 2). Five other species and species-groups were found on a regular basis; in approximate rank order they were American plaice, wolffishes (striped, spotted and broadhead), Greenland halibut, witch flounder and roughhead grenadier. Vahl's eelpout was often present, although its abundance was always very low. Fish assemblages of the deeper waters in this area have been treated by Snelgrove and Haedrich (1985).

W Deep Sub-Group. The W Deep Sub-Group occurred along the western slope of the Grand Bank. As mentioned, its boundary with the NES Deep Sub-Group lay between Jukes and Denys Canyons. The upper depth limit of this Sub-Group was as shallow as $100 \mathrm{~m}$, somewhat shallower than the upper limit of the NES Deep Sub-Group. Variability in that limit was mostly due to occasional incursions by redfish and hakes to shallower waters. Average depth of stations was around $250 \mathrm{~m}$ and there were high annual standard deviations, ranging from 60 to $90 \mathrm{~m}$. Bottom temperatures were mostly greater than $0^{\circ} \mathrm{C}$ and could reach $9^{\circ} \mathrm{C}$, the highest temperature recorded at the bottom during the surveys analyzed. One species dominated the W Deep Sub-Group: redfish. Haddock (since 1983), Greenland halibut (since 1978), cod, white hake and thorny skate followed in importance (Table 2). The abundance of these species in relation to redfish was much lower than in the NES Deep SubGroup. Other species usually present in low abundance were American plaice, other hakes (silver and longfin) and argentine. Angler and marlin-spike were commonly present though in very low abundance.

\section{Oceanographic Framework}

Ocean circulation on the Grand Bank is dominated by the southward-flowing cold Labrador Current (Smith et al., 1937; Lazier, 1982; Petrie and Anderson, 1983). To the south of the Bank, the warm North Atlantic Current flows offshore toward the east. Most of the volume transport of the Labrador Current occurs in a high velocity offshore core (temperature 3 to $4^{\circ} \mathrm{C}$, salinity around $34.9 \%$ ) over the $600-800 \mathrm{~m}$ isobath on the slope off Labrador. An inshore portion of the Current contains the greatest volume of cold water (temperature $-1^{\circ}$ to $+2^{\circ} \mathrm{C}$, salinity 32.5 to $33.5 \%$ ) and flows over the Labrador shelf or upper slope. Approaching the northern Grand Bank, the Labrador Current splits into three main branches: an inshore shelf stream through the Avalon Channel, a main branch along the eastern edge of the Bank and a third eastern component towards and around Flemish Cap (Fig. 1). There was a close relationship between the major physical oceanographic features of the Grand Bank and the distribution of the groundfish assemblages we have identified (Fig. 2).

The Avalon Group, with its low species diversity, was basically under the influence of the inshore branch of the Labrador Current. This branch is the coldest and least saline, probably accounting for the biological characteristics observed. Species richness in the Avalon Group was low and all the three dominant species (cod, American plaice and Arctic eelpout) tolerate very cold water $\left(<0^{\circ} \mathrm{C}\right)$.

The NE Intermediate Sub-Group could be called the 'Labrador Current main branch group', because the geographic areas covered by both roughly coincide. The main branch of the Labrador Current is generally confined between 50 and $200 \mathrm{~m}$ along the eastern edge of the Bank. This branch contains waters of the two different types present in the entire Labrador Current, and it bounds and interacts with the shelf water on the northern and eastern parts of the Bank. Bottom temperatures in the NE Intermediate area are usually higher and in a broader range than in the Avalon area. Thorny skate, less tolerant of negative temperatures than cod and American plaice, was absent in the Avalon Assemblage but present in the NE Intermediate region.

The NES Deep Sub-Group, basically characterized by the presence of redfish, apparently occurred underneath the position of the Labrador Current main branch where bottom temperatures are usually low but positive. Annual variability in the position of the upper limit of this Sub-Group, interpreted as shallow intrusions of redfish, may have depended on the depth of the Labrador Current main branch.

Warm waters of the North Atlantic Current sometimes penetrate the southern and southwestern parts of the Grand Bank. This penetration does not have the same magnitude every year and is spatially heterogeneous in relation to the bottom topography. A mixed water mass forms over the western, southern and southeastern slopes of the Bank from Atlantic water, the cold water from the Labrador Current, and, particularly over the western slope, 
the freshwater run-off from the St. Lawrence River (Forrester and Benoit, 1981). The SW Intermediate Sub-Group was under the influence of this mixed water, with very heterogeneous characteristics around the Bank. Bottom temperatures in the area occupied by this assemblage occurred over a broad $\left(-1.5^{\circ}\right.$ to $\left.+9^{\circ} \mathrm{C}\right)$ range.

The W Deep Sub-Group was clearly under the influence of warm slope water. Bottom temperatures in the $W$ Deep area were seldom negative with positive values as high as $11^{\circ} \mathrm{C}$ and average values between $3^{\circ}$ and $8^{\circ} \mathrm{C}$. The number of species present in hauls in this Sub-Group were among the highest recorded in spite of the fact that total biomass was strongly dominated by a single species, redfish. Other species usually found only there, with temperature range preferences suggested by Scott and Scott (1988) were common angler $\left(6^{\circ}\right.$ to $\left.10^{\circ} \mathrm{C}\right)$, pollock $\left(7^{\circ}\right.$ to $\left.15^{\circ} \mathrm{C}\right)$, marlin-spike $\left(3^{\circ}\right.$ to $\left.4^{\circ} \mathrm{C}\right)$, Atlantic argentine $\left(7^{\circ}\right.$ to $\left.10^{\circ} \mathrm{C}\right)$, haddock $\left(1^{\circ}\right.$ to $\left.13^{\circ} \mathrm{C}\right)$, spiny dogfish $\left(3^{\circ}\right.$ to $\left.15^{\circ} \mathrm{C}\right)$, silver hake $\left(6^{\circ}\right.$ to $\left.8^{\circ} \mathrm{C}\right)$, longfin hake $\left(3.5^{\circ}\right.$ to $\left.6.5^{\circ} \mathrm{C}\right)$ and white hake $\left(5^{\circ}\right.$ to $\left.11^{\circ} \mathrm{C}\right)$.

Shelf water on the central Grand Bank, the area of the Shallow Group, is a mixture of Labrador Current water and slope water, but there are modifications due to local seasonal heating. There is little detailed information available on water circulation in the area. Conflicting evidence exists concerning the presence of a gyre on the central part of the Grand Bank which could be responsible for an apparent retention of water there (Smith et al., 1937; Buzdalin and Elizarov, 1962; Forrester and Benoit, 1981).

\section{The Biological Coherence of Assemblages}

Multivariate techniques are useful tools for taking a first exploratory step towards defining faunal assemblages. The next step is to identify those that are biologically coherent. A biologically coherent assemblage is one in which the components (fish populations in our case) are totally enclosed within it, as opposed to, for example, an assemblage whose area encompasses only an ontogenic phase of a given population with the other ontogenic phases in areas of other contiguous assemblages. A coherent assemblage is most easily recognized when its species are exclusive to that assemblage. Yellowtail flounder, for example, seemed exclusive to the Shallow Assemblage. Regardless of whether it was composed of one or several populations, the Shallow Assemblage was coherent with respect to yellowtail flounder. The same was not true with regard to cod, a species that was important in all assemblages identified.

Where ubiquitous recurrent species are respon- sible for a part of the overlap between assemblages, further investigation is required to judge how coherent and natural are the assemblages yielded by the multivariate analysis. One might end up fusing areas belonging to initially separated assemblages if they share populations comprising an important proportion of the total biomass. A brief literature review was carried out for the dominant groundfish species in order to confront the assemblages we identified with the biological information on their populations. The results follow:

Atlantic cod. Based on analysis of meristics, tag data, growth rate, parasite loads and allele frequencies (Templeman, 1962, 1974; Lear, MS 1985, MS 1986) there seemed to be no support for keeping the Avalon Assemblage distinct from the point of view of this species. In keeping with current practice it will be assumed that this assemblage had more affinities with the NE Intermediate Group (NAFO Div. 3L) than with the Shallow Assemblage.

Yellowtail flounder. The Shallow Assemblage encompassed the bulk of the yellowtail flounder distribution on the Grand Bank. This species is found in all shallow waters of NAFO Div. 3LNO, although the majority of the commercial catch comes from Div. 3N (Brodie and Walsh, MS 1988). It is also found in small amounts on St. Pierre Bank and in inshore areas around the Avalon Peninsula (Pitt, 1970). Yellowtail flounder is a shallow water species with relatively restricted movements (Lux, 1963; Walsh, MS 1987). Stock delimitation within the Shallow Assemblage area, if any, is not known. Yellowtail flounder has been managed as a single stock on the Grand Bank and there seems to be no good reason to join the Shallow Assemblage with any other assemblage based on this species.

American plaice. American plaice has also been managed as a single stock on the Grand Bank. Its distribution is fairly wide (Walsh and Brodie, MS 1988), ranging from deep water concentrations (520 $\mathrm{m}$ ) in the northern part of our NES Deep Assemblage to a juvenile nursery in shallow waters of the Tail of the Bank. Majority of the biomass, as described by Walsh and Brodie (MS 1987), was in the ShallowIntermediate waters (55-180 m). They appear to move very little once the young settle and little intermingling is expected among adults. The strongest suggestion for merging assemblages from the point of view of this species is between the Shallow and NE Intermediate Assemblages, but evidence was not considered strong enough to take this action.

Redfish. There are three redfish species on the Grand Bank, the abundant beaked redfishes (Sebastes mentella and Sebastes fasciatus) and 
the more sporadic golden redfish (Sebastes marinus). Ni (MS 1981a, MS 1981b) presented evidence that $S$. fasciatus was dominant in the shallower range and $S$. mentella was dominant in the deeper parts. Sampling stations during the surveys analyzed in our work seldom went deeper than $500 \mathrm{~m}$ and in most cases were shallower than $400 \mathrm{~m}$. The redfish in the Deep Assemblage was therefore assumed to be mostly $S$. fasciatus. We also followed the usual NAFO practice of separating redfish in Div. 30 from Div. 3LN.

\section{Merging Assemblages}

There is evidence that some of the groundfish populations which make up an important percentage of the biomass in the Grand Bank assemblages extend their geographic distribution over more than one assemblage. This underlines the need for reformulating the initial assemblages if a biologically acceptable spatial scale for studies at the community level is intended.

The Deep Assemblage was dominated by beaked redfish, deep-water species caught in very small amounts in all of the Intermediate area. Cod in the NES Deep Sub-Group area may have belonged to the northern complex while in the W Deep Sub-Group cod biomass was relatively low. Cod did not seem to offer any good reason for merging any Deep and Intermediate groups. The same was true for American plaice. The Deep Sub-Groups were therefore kept separate.

The Avalon and NE Intermediate Sub-Groups were merged into a Northeastern Region (or Northeastern Grand Bank). The Shallow and SW Intermediate Sub-Group were merged into a Southern Region (or Southern Grand Bank). These decisions were made in keeping with current evidence and practice regarding the structure of the cod stocks, with those taken south of $46^{\circ} \mathrm{N}$ latitude being associated with the Div. $3 \mathrm{NO}$ stock, and others, particularly those from the northern Grand Bank and Avalon Channel, treated separately. There are therefore four broad areas with relative biological homogeneity on the Bank in regard to groundfish: NES Deep, W Deep, Northeastern Region and Southern Region. Having reached this conclusion regarding coherence, trends in biomass and species composition over time were then considered for the Northeastern and Southern Regions, as well as for the entire Grand Bank.

\section{Catch Trends in the Grand Bank Fish Assemblages}

Hereafter, the focus is on the two larger zoogeographic regions on the Bank proper, the Northeastern and Southern Regions, mainly because knowl- edge of the outer limits of the Deep Region (dashed lines in Fig. 2) was seriously constrained by sampling limitations. CPUE (kg/tow) from the groundfish surveys (1971-82, 1984-87) were used as an index of biomass abundance for the Southern and Northeastern Regions, and for the entire Grand Bank. Species composition of the catch was used to construct cumulative percentage graphs (Figs. 3, 4, 5).

\section{Southern Region}

Cod, American plaice, yellowtail flounder and thorny skate dominated the biomass of demersal catches in this assemblage (Fig. 3), which extended over almost all of the shallow Bank. The index of total abundance fluctuated around $150 \mathrm{~kg} / \mathrm{tow}$ since 1973 but rose to over $200 \mathrm{~kg} / \mathrm{tow}$ after 1984. This peak followed a rising trend in the biomass of cod.

\section{Northeastern Region}

The broad area comprised by this assemblage was dominated by only two species - American plaice and cod (Fig. 4). Total CPUE has been stable at over $150 \mathrm{~kg} /$ tow since 1976, but there has been a shift in relative abundance of cod and American plaice in the catches since 1982. An increase in the catch rates for cod since 1982 was matched by a decrease in American plaice.

\section{Entire Grand Bank}

The biomass of demersal groundfish catches on the Grand Bank during the time period analyzed was dominated by a small number of species (Fig. $5)$. The index of total abundance has fluctuated around $200 \mathrm{~kg} /$ tow with relatively higher values since 1984. This high was apparently due to an increasing trend in the catch rate of cod observed in all assemblages except the deep ones (Gomes, MS 1991). Other species, like yellowtail flounder or American plaice, remained relatively stable or, like redfish, did not exhibit any pronounced trends.

\section{Discussion}

\section{Assemblage validity}

Classificatory analysis of 16 years of spring groundfish survey data indicated a high degree of spatial consistency in the clustering pattern of stations and in the species that characterize each cluster. The Grand Bank could be divided into six areas defined on the basis of groundfish assemblages. These were mapped (Fig. 2), described, and reformulated for biological coherence. The assemblages maintained their species composition over the time period analyzed, and year after year retained the major attributes of their spatial configuration (Gomes et al., 1989; Gomes, MS 1991). It is emphasized, however, that the assemblage areas defined are primarily representative of species that 

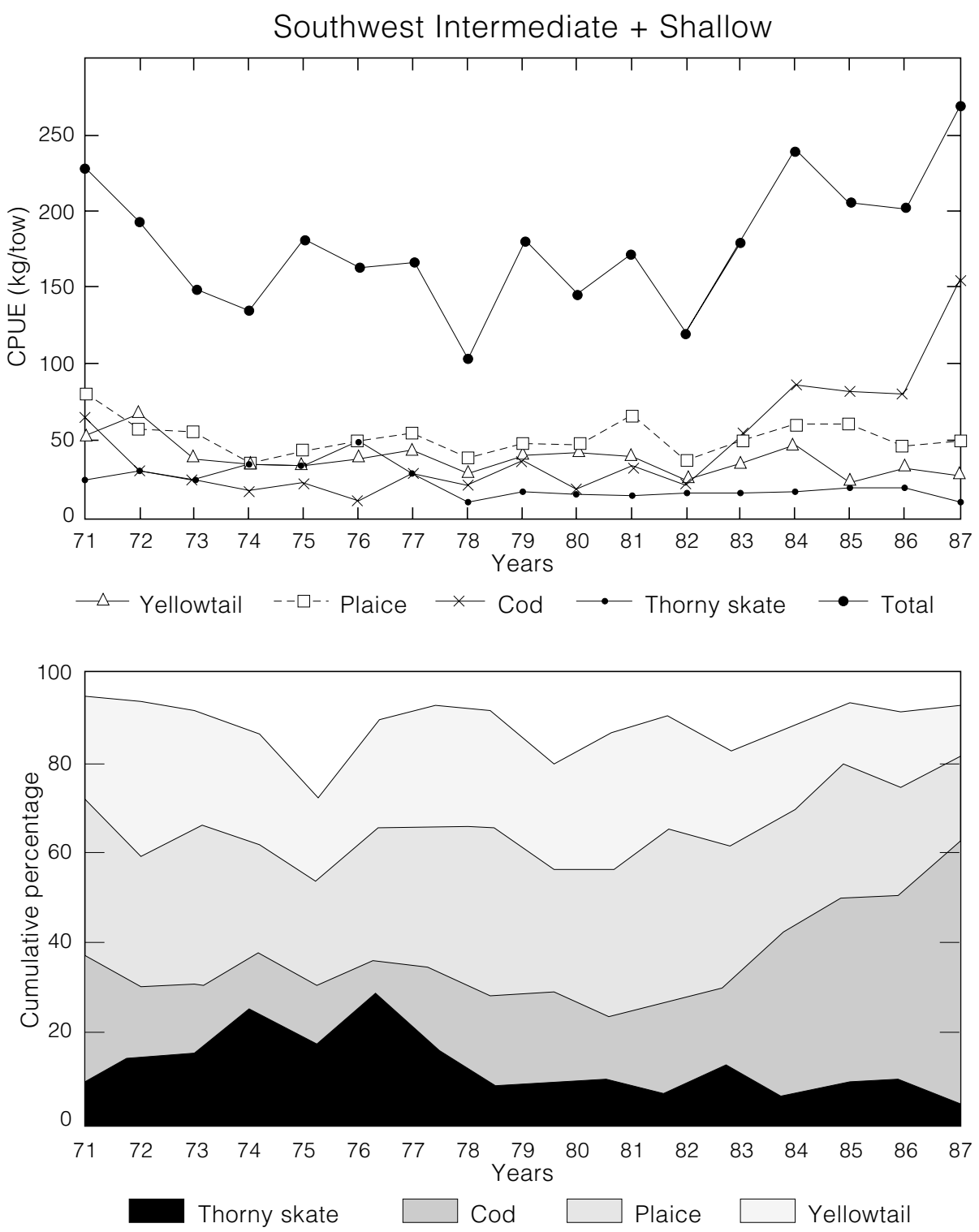

Fig. 3. Trends in species abundance in the Southern Region. The line graph presents trends in $\mathrm{kg} /$ tow of spring trawl surveys. The shadowed graph presents relative proportions (cumulative percentage) of the main species.

are vulnerable to the demersal trawl surveys in spring. This includes some of the most abundant and commercially important species on the Bank. There are common methodological problems involved in this type of analysis (Mahon et al., 1984; Gabriel and Murawski, 1985) which we will briefly address.

The intrinsic variance of fish samples may result in the misallocation of stations by the clustering procedure selected. We sought to overcome this by using a reallocation procedure, mapping the clusters, and by checking the agglomeratively built dendrograms against a divisive, and more robust, method. Even so, one cannot preclude misclassifications. Stations occurring near assemblage boundaries on the steep continental slope at the edge of the Bank are particularly prone to this. It was nevertheless reassuring to find that there seemed to be some uniformity in major physical oceanographic variables within each area identified. The unusually long time-period covered, 17 years, was also a valuable guarantee of the validity of these assemblage areas. If two species co-occur in a given area only during a short period of time, say 1 or 2 years, there is usually little sense in 

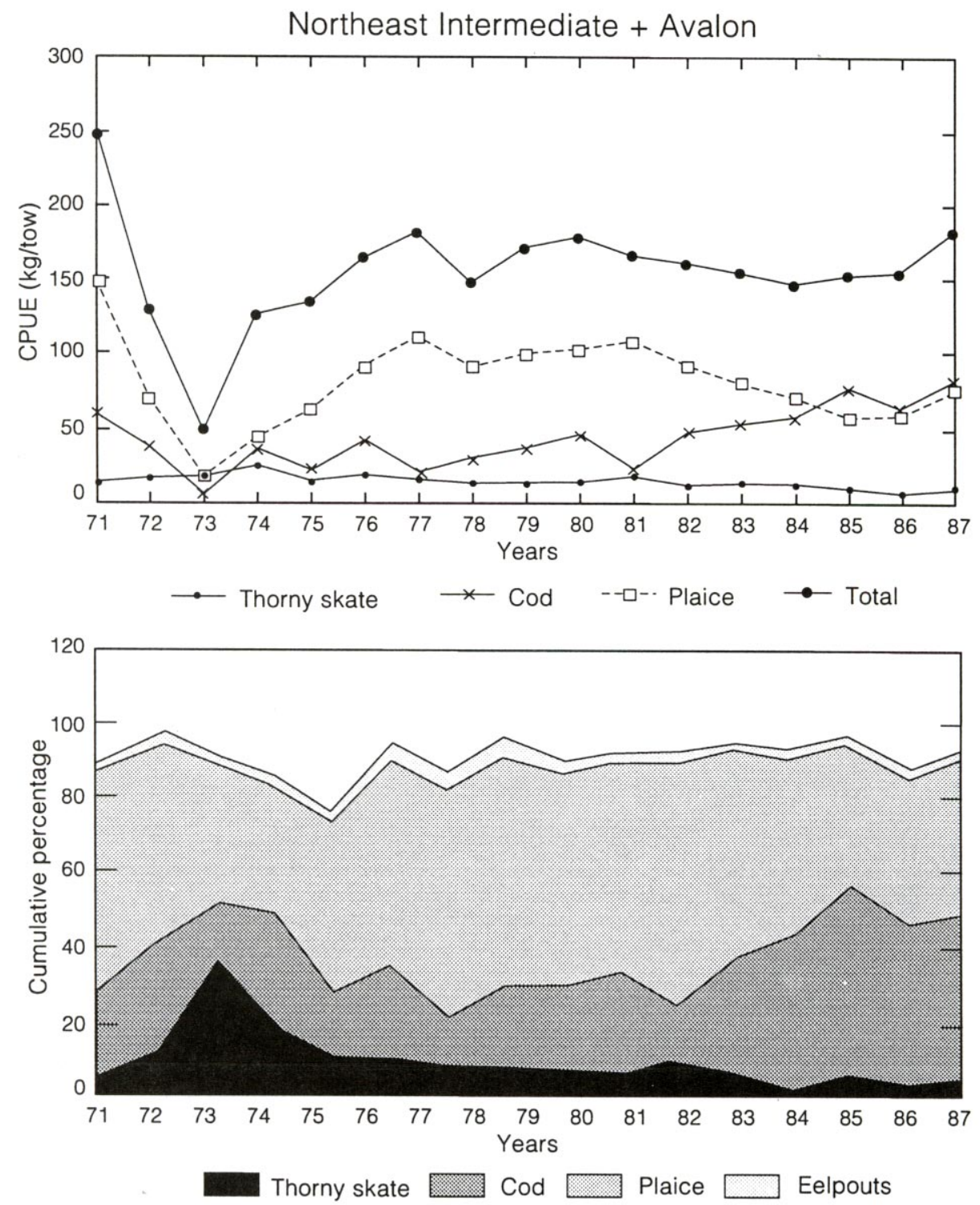

Fig. 4. Trends in species abundance in the Northeastern Region. The line graph presents trends in $\mathrm{kg} / \mathrm{tow}$ of spring trawl surveys. The shadowed graph presents relative proportions (cumulative percentage) of the main species.

including them in the same assemblage. Persistence, that is the ability of an assemblage to maintain its species composition over time, is an important requirement for assemblage validity.

Worldwide studies of marine demersal fish assemblages have shown that the main biogeographic contours on continental shelves and slopes are strongly aligned with depth (Fager and Longhurst, 1968; Haedrich and Krefft, 1978; Overholtz, MS 1983; Gabriel, MS 1983; Colvocoresses and Musick, 1984; Mahon et al., 1984; Gomes, MS 1987). A variety of physical factors such as light level, pres- sure, water mass characteristics and sediment properties are also associated with depth change. Local influences of some of these factors have been suggested to be responsible for a variety of deviations from a simple depth-aligned biogeography. Nevertheless, it has usually been possible to recognize, without much trouble, a characteristic group of species that dominates the shallow portion of the continental shelf within a restricted depth range. Easily recognizable also is a group of deep dwellers dominating portions of the continental slope, a group which tends to have a much broader depth range than the shallow shelf group. Intermediate groups 

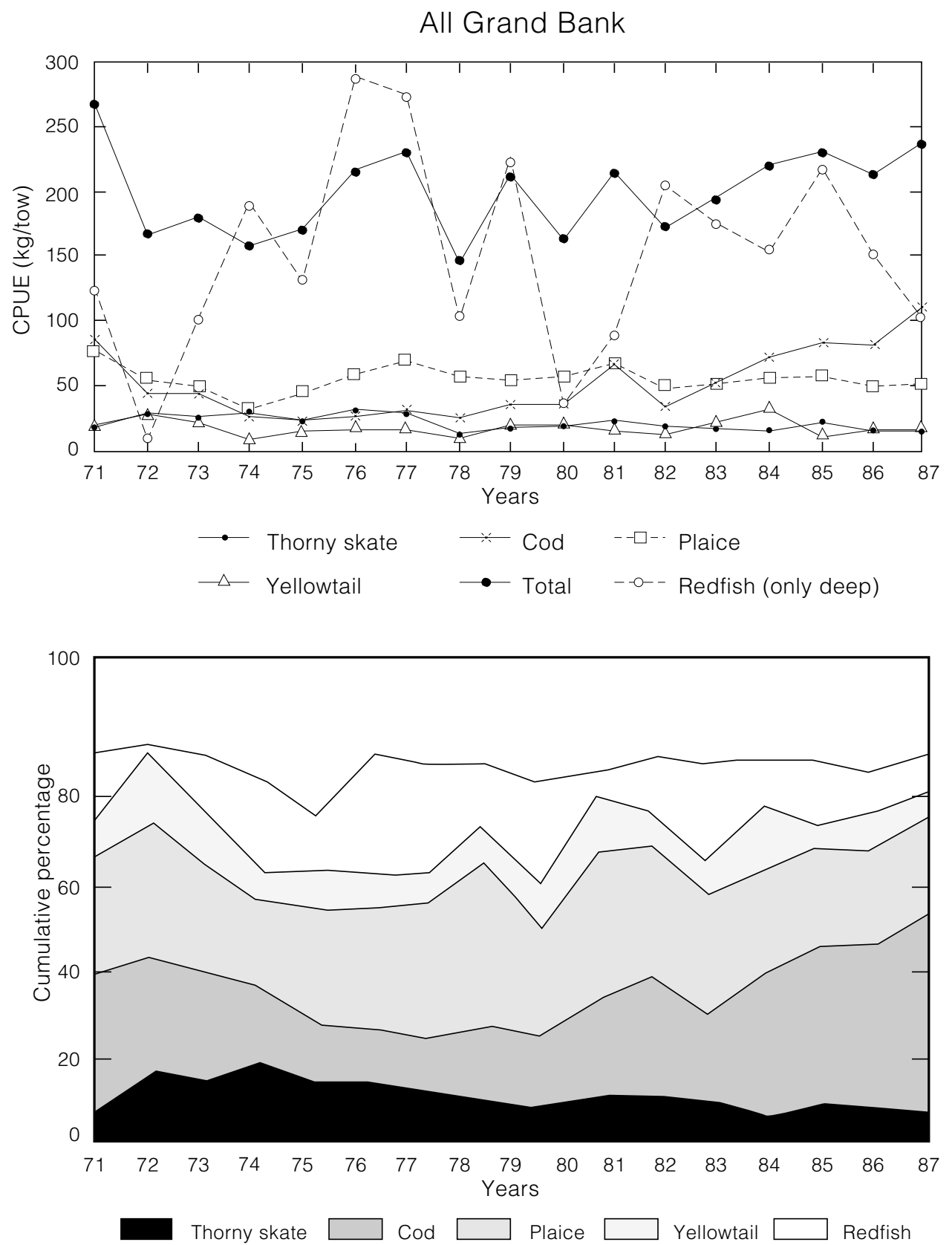

Fig. 5. Trends in species abundance for the entire Grand Bank. The line graph presents trends in $\mathrm{kg} / \mathrm{tow}$ of spring trawl surveys. The shadowed graph presents relative proportions (cumulative percentage) of the main species.

between these two extremes have been identified, but are usually more difficult to characterize. They are sometimes no more than a mix of species from the shallow and deep groups with no abundant or distinctive species of their own.

The fish assemblages we identified on the Grand Bank (Fig. 2) fit well into this general picture. The assemblage contours were strongly aligned with depth and the general oceanographic circulation of the area. Yellowtail flounder and redfish were the typical abundant representatives from the shallow and deep areas respectively, while cod, American plaice and thorny skate were abundant and widespread enough over the whole area to raise problems when attempting to compartmentalize the Bank.

\section{Spatial scale}

Multivariate methods require decisions about the scale of approach to spatially aggregated data. In the case of cluster analysis, this translates into 
decisions about the dendrogram level at which the clusters are defined. In our attempt to identify biologically coherent assemblages, we first approached the entire Grand Bank at medium-high levels of hierarchical clustering, and then merged areas according to strong biological constraints, namely stock delimitation of the most abundant species. We suggest that the four zoogeographic areas identified (NES Deep, W Deep, Northeastern, Southern) define a useful and realistic spatial scale for multispecies studies involving abundant species on the Grand Bank. Given the mobility of most pelagic species and their apparent widespread distribution on the Bank, it seems unlikely that biological coherence will be preserved with further horizontal subdivisions. Gomes (MS 1991), however, from a literature review of feeding interactions on the Grand Bank, has suggested a possible additional "vertical" subdivision into pelagic and benthic groups within the Northeastern and the Southern Regions.

\section{Interactions within assemblages}

The pragmatic way of grouping species that we have used, based on coincidence of geographic distributions, does not necessarily imply significant interactions among the species of each assemblage. Multivariate techniques in and of themselves bring little insight to the question of the influence of abiotic factors versus species interactions in determining the observed distribution patterns. The autecological view (Mclntosh, 1985) that has dominated fisheries biology (Rigler, 1982) may question the value of our zoogeographic regions for multispecies studies except, perhaps, for very widespread species. There is, however, a complex network of trophic interactions within the Northeastern and Southern Regions (Fig. 6) that involve the most abundant species and suggest the possibility of a synecological approach to the Grand Bank community. The extent to which populations influence each other's growth rates as a consequence of these interactions is, however, by no means clear, and there is a considerable degree of uncertainty when one attempts to build multispecific models for each zoogeographic region with predictive goals in mind (Gomes, MS 1991; Gomes and Haedrich, 1992).

Regardless of the actual balance between biotic and abiotic factors in determining the observed

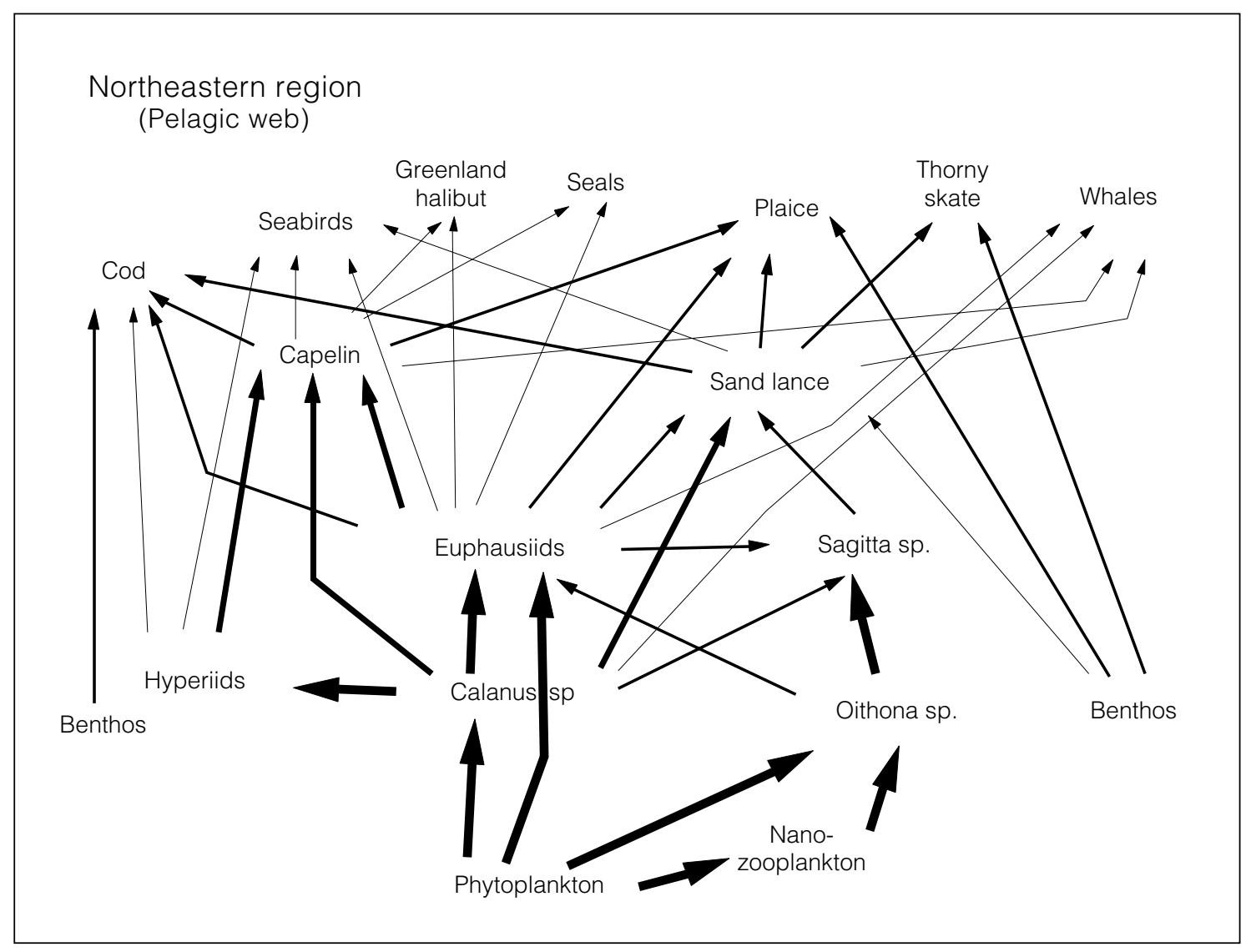

Fig. 6. Major taxa and their trophic relationships in the water column of the Northeastern Grand Bank Region (from Gomes, MS 1991). 
patterns of Fig. 2, the simple definition of relatively homogeneous areas in terms of species composition has relevance to multispecies management (Mahon et al., 1984). Mixed catches within the area of a given assemblage offer a certain redundancy in terms of species composition and relative abundances. Such information can be of value in dealing with by-catch and providing general guidelines for overall rational planning and management.

\section{Acknowledgements}

We are indebted to the staff of the Northwest Atlantic Fisheries Centre, Department of Fisheries and Oceans; without their planning and long-term efforts in assembling the basic data, this work would have been impossible. We thank D. Schneider (Ocean Sciences Center, Memorial University) and G. Lilly (Dept. of Fisheries and Oceans) for comments on early drafts. Our thanks also to David MacNeil, Earth Sciences, Memorial University, for providing expert computer mapping. Financial support for M. C. Gomes has been provided by the Junta Nacional de Investigação Científica e Tecnológica (JNICT), Lisbon, Portugal. Support came also from a Natural Sciences and Engineering Research Council (NSERC) grant to R.L. Haedrich.

\section{References}

AUSTER, P.J. 1988. A review of the present state of understanding of marine fish communities. J. Northw. Atl. Fish. Sci., 8: 67-75.

BATAGELJ, V. 1988. Generalized Ward and related clustering problems. In: Classification and Related Methods of Data Analysis, p. 67-74. H.H.Bock (ed.) Elsevier Sci. Publ. B.V., North-Holland.

BLOOM, S.A. 1981. Similarity indices in community studies: potential pitfalls. Mar. Ecol. Prog. Ser., 5: 125128.

BRODIE, W.B., and S.J. WALSH. MS 1988. An update on the status of the yellowtail flounder stock in Divisions 3LNO. NAFO SCR Doc., No. 38, Serial No. N1475, 42 p.

BUZDALIN, Y.I., and A.A. ELIZAROV. 1962. Hydrological conditions in the Newfoundland Banks and Labrador areas in 1960. In: Soviet Fisheries Investigations in the Northwest Atlantic, Yu. Yu. Marti (ed.), VNIROPINRO, Moscow. (Transl. from Russian by the Israel Prog. for Sci. Transl., 1963, p. 152-168.)

CLIFFORD, H.T., and W. STEPHENSON. 1975. An Introduction to Numerical Classification. Academic Press, New York, $229 p$

COLVOCORESSES, J.A., and J.A. MUSICK. 1984. Species associations and community composition of Middle Atlantic Bight continental shelf demersal fishes. Fish. Bull. U.S., 82: 295-313.

FAGER, E.W., and A.R. LONGHURST. 1968. Recurrent group analysis of species assemblages of demersal fish in the Gulf of Guinea. J. Fish. Res. Board Can., 25: 1405-1421.

FORRESTER, W.D., and J. BENOIT. MS 1981. Physical oceanography of waters over the Grand banks of
Newfoundland. In: Grand Banks Oceanographic Studies. Final Report vol. 1, sec. III. Prepared for Mobil Oil Canada, Ltd. by MacLaren Plansearch.

GABRIEL, W.L. MS 1983. Structure and Dynamics of Northeastern Pacific Demersal Fish Assemblages. Ph.D. Thesis, Oregon State University, Cornvallis, $298 \mathrm{p}$.

GABRIEL, W.L., and S.A. MURAWSKI. 1985. The use of cluster analysis in identification and description of multispecies systems. In: Toward the inclusion of fishery interactions in management advice. R. Mahon (ed.). Tech. Rep. Can. Fish. Aquat. Sci., 1347: 112117.

GAUCH, H.G. 1982. Multivariate Analysis in Community Ecology. Cambridge University Press, Cambridge, $298 \mathrm{p}$.

GOMES, M.C., MS 1987. Factorial Analysis in Ecology. Application to the Study of the Demersal Fauna of the Portuguese Shelf. M.Sc. Thesis, Fac. Science, University of Lisbon (in Portuguese), $149 \mathrm{p}$.

MS 1991. Predictions Under Uncertainty: Fish Assemblages and Food Webs on the Grand Bank of Newfoundland. Ph.D. Thesis, Memorial University of Newfoundland, St. John's, $230 \mathrm{p}$.

GOMES, M.C., and R.L. HAEDRICH. 1992. Predicting community dynamics from food web structure. In: Deep-Sea Food Chains and the Global Carbon Cycle, p. 277-293. G.T. Rowe and V. Pariente (eds.), (Proceedings of the NATO Advanced Research Workshop, April 1991), Kluwer, Dordrecht, The Netherlands.

GOMES, M.C., J. RICE, and R.L. HAEDRICH. MS 1989. Fish assemblages on the Grand Bank of Newfoundland. NAFO SCR Doc., No. 75, Serial No. N1656, $31 \mathrm{p}$.

HAEDRICH, R.L., and G. KREFFT. 1978. Distribution of bottom fishes in the Denmark Strait and Irminger Sea. Deep-Sea Res., 25: 705-720.

HILL, M.O. 1979. TWINSPAN-FORTRAN Program for arranging multivariate data in an ordered two-way table by classification of the individuals and attributes. Ecology and Systematics, Cornell Univ., Ithaca, N.Y., $90 \mathrm{p}$.

HILL, M.O., R.G. BUNCE and M.W. SHAW. 1975. Indicator species analysis, a divisive polythetic method of classification, and its application to a survey of native pinewoods in Scotland. J. Ecol., 63: 597-613.

JARDINE, N. , and R. SIBSON. 1971. Mathematical Taxonomy. Wiley, $286 \mathrm{p}$.

LAMBERT, J.M., and W.T. WILLIAMS. 1962. Multivariate methods in plant ecology. IV. Nodal analysis. J. Ecol., 50: 775-802.

LAZIER, J.R. 1982. Seasonal variability of temperature and salinity in the Labrador Current. J. Mar. Res., 40 (Supplement): 341-356.

LEAR, W.H. MS 1985. Migration and intermingling of cod in relation to the Canadian 200-mile limit around the nose (NAFO Div. 3L) and the tail (NAFO Div. 3N) of the Grand Bank. NAFO SCR Doc., No.40, Serial No. N990,14 p.

MS 1986. A further discussion of the stock complex of Atlantic cod in NAFO Div. 2J, 3K and 3L. NAFO SCR Doc., No. 118, Serial No. N1245, 18 p.

LUX, F.E. 1963. Identification of New England yellowtail flounder groups. Fish. Bull. U.S. 63: 1-10.

MAHON, R. (ed.) 1985. Toward the inclusion of fishery interactions in management advice. Proceedings of 
a workshop at the Bedford Institute of Oceanography (Oct 30-Nov 1, 1984). Tech. Rept. Can. Fish. Aquat. Sci., 1347: $221 \mathrm{p}$.

MAHON, R., R.W. SMITH, B.B. BERNSTEIN, and J.S. SCOTT. 1984. Spatial and temporal patterns of groundfish distribution on the Scotian Shelf and in the Bay of Fundy, 1970-1981. Tech. Rept. Can. Fish. Aquat. Sci. 1300: $164 \mathrm{p}$.

MAY, R.M. [ed.] 1984. Exploitation of Marine Communities. Report of the Dahlem Workshop on Exploitation of Marine Communities, Berlin 1984. Springer-Verlag, Berlin, $366 \mathrm{p}$.

McINTOSH, R. P. 1985. The Background of Ecology. Concept and Theory. Cambridge University Press, Cambridge, $383 \mathrm{p}$.

MEGREY, A.B., and V. G. WESPESTAD. 1988. A review of biological assumptions underlying fishery assessment models, p. 31-69. In: Fishery Science and Management. W.S. Wooster (ed.) Springer-Verlag, Berlin.

MERCER, M.C. (ed.) 1982. Multispecies approaches to fisheries management advice. Can. Spec. Publ. Fish. Aquat. Sci., 59: 169 p.

NI, I-H. MS 1981a. The use of vertebrae frequencies to indicate the distribution of sharp-beaked redfish, Sebastes mentella and Sebastes fasciatus. NAFO SCR Doc., No. 70, Ser. No. N354: 17 p.

MS 1981b. The use of anal fin ray frequencies to indicate the stock units of deepwater redfish, Sebastes mentella and rosefish, Sebastes fasciatus. NAFO SCR Doc., No. 80, Serial No. N365,14 p.

O'NEILL, R.V. 1989. Perspectives in hierarchy and scale. In: Perspectives in Ecological Theory. J. Roughgarden, R. M. May, and S. A. Levin (eds.). Princeton Univ. Press, Princeton, NJ, p. 140-156.

O'NEILL, R.V., D.L. DEANGELIS, J.B. WAIDE and T.F. ALLEN. 1986. A Hierarchical Concept of Ecosystems. Princeton Univ. Press, Princeton, NJ.

OVERHOLTZ, W.J. MS 1983. Long-term Temporal Perspectives for the Demersal Fish Assemblages of Georges Bank with Implications for Management and Modelling. Ph.D. Thesis, Oregon State University, Corvallis, $243 \mathrm{p}$.

PETRIE, B. and C.ANDERSON. 1983. Circulation on the Newfoundland Continental Shelf. Atmosphere-Ocean, 21: 207-226.

PITT, T.K. 1970. Distribution, abundance and spawning of yellowtail flounder, Limanda ferruginea, in the Newfoundland area of the northwest Atlantic. J. Fish. Res. Board Can., 27: 2261-2271.

POWELL, T.M. 1989. Physical and biological scales of variability in lakes, estuaries, and the coastal ocean, p. 157-176. In: Perspectives in Ecological Theory. J. Roughgarden, R. May, and S. A. Levin (eds.) Princeton Univ. Press, Princeton, NJ.

RIGLER, F.H. 1982. The relation between fisheries management and limnology. Trans. Amer. Fish. Soc., 111: $121-132$.

SCOTT, W., and M. SCOTT. 1988. Atlantic Fishes of Canada. Can. Bull. Fish. Aquat. Sci., 219: 731 p.

SINCLAIR, A.F. 1985. Fishery distribution on the Scotian Shelf. Toward the inclusion of fishery interactions in management advice. In: R. Mahon (ed.). Tech. Rept. Can. Fish. Aquat. Sci., 1347: 183-193.

SMITH, E.H., F.M. SOULE, and O. MOSBY. 1937. The Marion and General Greene expeditions to Davis Strait and Labrador Sea. Bull. U.S. Coast Guard, 19: pt. 2, 25-27.

SNELGROVE, P., and R. L. HAEDRICH. 1985. Structure of the deep demersal fish fauna off Newfoundland. Mar. Ecol. Prog. Ser., 27: 99-107.

TEMPLEMAN, W. 1962. Division of cod stocks in the northwest Atlantic. ICNAF Redbook, 1962(III): 79123.

1974. Migrations and intermingling of Atlantic cod (Gadus morhua) stocks of the Newfoundland area. J. Fish. Res. Bd. Canada, 31: 1073-1092.

TYLER, A.V., W.L. GABRIEL, and W.J. OVERHOLTZ. 1982. Adaptive management based on structure of fish assemblages of northern continental shelves, In: Multispecies approaches to fisheries management advice, M.C.Mercer (ed.). Can. Spec. Publ. Fish. Aquat. Sci. 59: p.149-156.

UNDERWOOD, A.J. 1986. What is a community? p. 351367. In: Patterns and Processes in the History of Life, D. Raup and D. Jablonski (eds.) Springer-Verlag, Berlin.

WALSH, S. MS 1987. Some observations on the movement of tagged yellowtail flounder (Limanda ferruginea) on the Grand Bank, NAFO Div. 3LNO. NAFO SCR Doc., No.46, Serial No. N1325, 5 p.

WALSH, S., and W.B. BRODIE. MS 1987. Aspects of American plaice distribution in NAFO Div. $3 \mathrm{~L}, 3 \mathrm{~N}$ and 3O. NAFO SCR Doc., No. 47, Serial No. N1334, 12 p.

MS 1988. American plaice distribution on the nose and tail of the Grand Bank. NAFO SCR Doc., No.28, Ser. No. N1464: 12 p.

WARD, J.H. 1963. Hierarchical grouping to optimize an objective function. J. Amer. Stat. Assoc., 58: 236244.

WISHART, D. 1982. CLUSTAN - User manual of Clustan Analysis Package. Program Library Unit, Edinburgh University, $175 \mathrm{p}$. 